SHORT REPORT

\title{
Occupational asthma caused by cellulase and lipase in the detergent industry
}

\author{
A Brant, A Hole, J Cannon, J Helm, C Swales, J Welch, A Newman Taylor, P Cullinan
}

Occup Environ Med 2004;61:793-795. doi: 10.1136/oem.2003.011288

Three employees from two different detergent companies were investigated for occupational asthma, using skin prick tests, serum specific lgE, and specific bronchial challenge. Two were challenged with lipase and one with cellulase. All three cases had immunological evidence of sensitisation to the detergent enzymes with which they worked. Bronchial challenge in each provoked a reproducible dual asthmatic response, which reproduced their work related symptoms. These are the first reported cases of occupational asthma attributable to cellulase and lipase in the detergent industry. Four of the most common enzymes used in this industry have now been reported to cause occupational asthma; continued vigilance and caution are needed when working with these or other enzymes.

$\mathrm{P}$ roteases, added to washing detergents to improve their cleansing properties, are a well established cause of occupational asthma. Following their introduction as powders into detergents in the 1960s, cases of sensitisation and asthma occurred in both workers and consumers. ${ }^{1-3}$ The industry largely resolved the problem by encapsulating the enzyme and changing engineering processes. ${ }^{4}$ Over the past 15 years other enzyme types such as amylases, cellulases, and lipases have been introduced for their cleansing properties. We recently described four cases of occupational asthma caused by detergent bacillary amylase. ${ }^{5}$ Here we present cases of occupational asthma caused by two further detergent enzymes: a cellulase derived from Humicola insolens and a genetically engineered lipase from Aspergillus oryzae. The patients worked at two different detergent manufacturing companies, both using encapsulated enzymes, and were referred to a specialist clinic for investigation of possible occupational asthma.

\section{METHODS}

\section{Immunological testing}

Each patient had skin prick tests to common aeroallergens (cat dander, grass pollen, and Dermatophagoides pteronyssinus; Allergopharma, Germany) and to $1 \mathrm{mg} / \mathrm{ml}$ solutions of the detergent enzymes to which they had been exposed at work. A positive skin test result was defined as one with a wheal diameter of $\geqslant 3 \mathrm{~mm}$. Circulating specific IgE to the same enzymes was measured by radioallergosorbent (RAST) assay, with binding $\geqslant 2 \%$ considered positive.

\section{Bronchial provocation testing}

Because, in spite of the characteristic histories, other investigations were not diagnostic of occupational asthma, we undertook specific bronchial challenge in each case. All of the cases were still working with enzymes; none had ever taken bronchial anti-inflammatory medications. A single

\section{Main messages}

- Cellulase and lipase cause occupational asthma in the detergent industry.

- All enzymes should be considered to be potential respiratory sensitisers.

\section{Policy implications}

- Continued vigilance and appropriate preventative measures need to be taken by those working with enzymes.

Table 1 Immunological findings and specific bronchial challenges

\begin{tabular}{|c|c|c|c|c|c|}
\hline & $\begin{array}{l}\text { Enzymes at place } \\
\text { of work }\end{array}$ & $\begin{array}{l}\text { Skin prick test } \\
(\text { size, mm) }\end{array}$ & RAST $\%$ binding & $\begin{array}{l}\text { Challenge } \\
\text { substance }\end{array}$ & Bronchial response \\
\hline \multirow[t]{3}{*}{ Case 1} & Cellulase & 6 & 25 & Cellulase & Dual \\
\hline & Protease & 4 & 8 & & \\
\hline & Amylase & 6 & 7 & & \\
\hline \multirow{4}{*}{ Case 2} & Lipase & 10 & 16 & Lipase & Dual \\
\hline & Protease & 7 & 23 & & \\
\hline & Amylase & 7 & 62 & & \\
\hline & Cellulase & 5 & nd & & \\
\hline \multirow[t]{4}{*}{ Case 3} & Lipase & 6 & 38 & Lipase & Dual \\
\hline & Protease & 0 & 0.9 & & \\
\hline & Amylase & nd & 0.6 & & \\
\hline & Cellulase & 0 & 1.3 & & \\
\hline
\end{tabular}



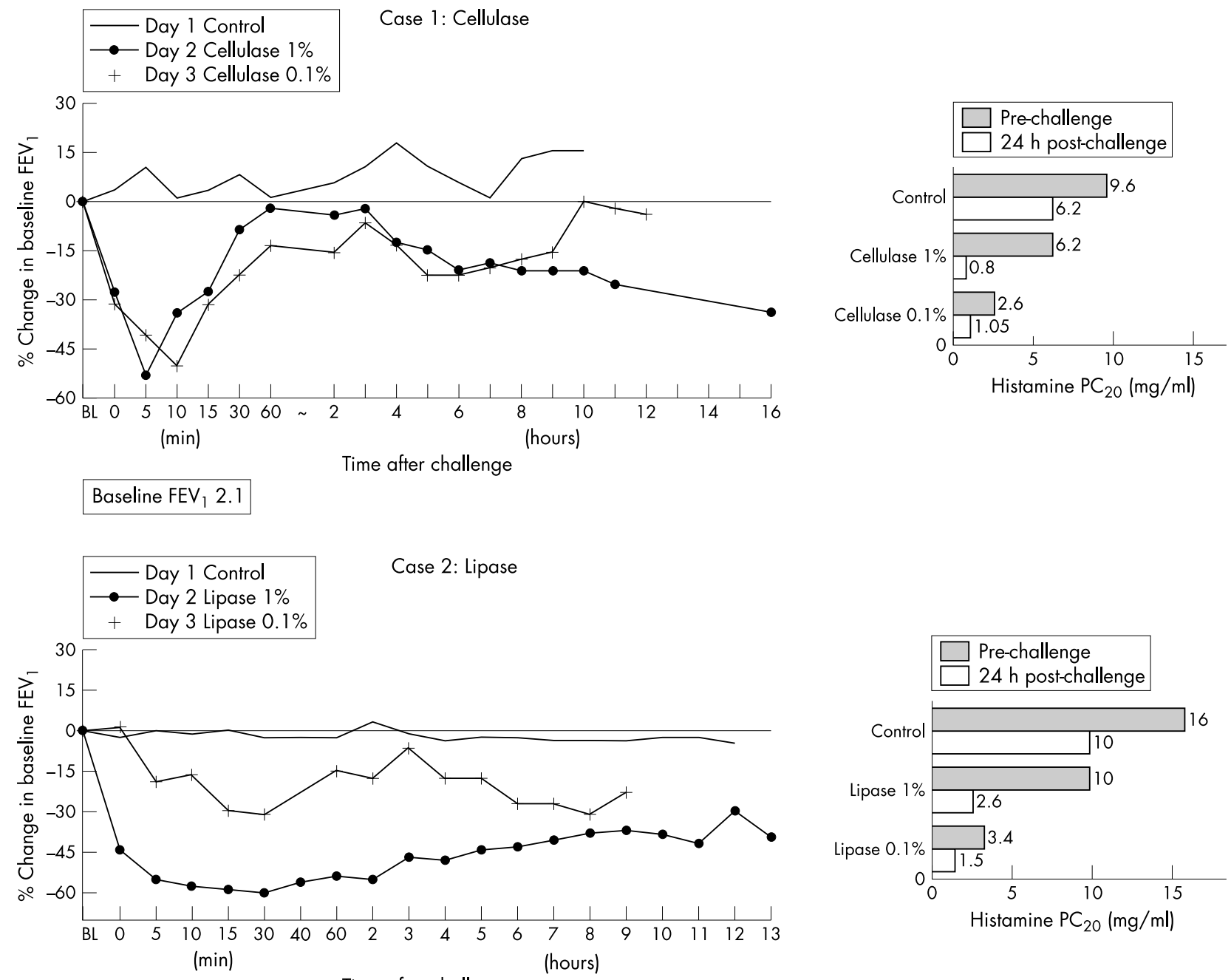

Baseline $\mathrm{FEV}_{1} 4.1$
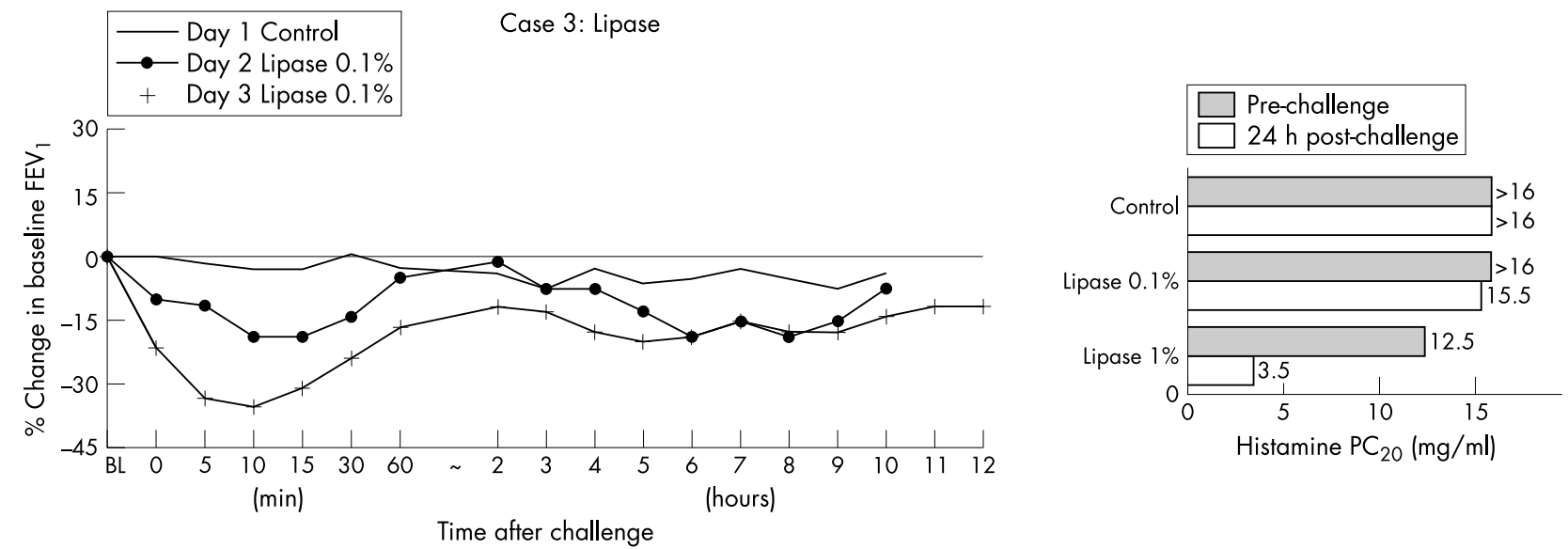

Baseline $\mathrm{FEV}_{1} 4.3$

Figure 1 Specific bronchial challenges: changes in baseline $\mathrm{FEV}$ and histamine $\mathrm{PC}_{20}$.

blind, dust tipping method was used with lactose (first exposure day) as an inert control. Granulated enzymes provided by the employers were crushed by hand with a pestle and mortar and mixed with lactose powder. Each case was challenged with a single enzyme, with separate test exposures on separate days. Forced expiratory volume in 1 second $\left(\mathrm{FEV}_{1}\right)$ was measured regularly in the first hour, and hourly for the next $12-16$ hours. $\mathrm{PC}_{20}$ to inhaled histamine was measured by the Cockroft method before, and 24 hours after, the challenge. 


\section{RESULTS}

The results of the immunology and bronchial provocation test in the three cases are summarised in table 1 and fig 1 .

\section{Case 1: Cellulase}

A 48 year old woman had worked in a detergent factory since 1990, nine years as a packer, and one year each as a cleaner and in the product development laboratory. In 1995 she developed work related running of the eyes and nose, and in 2001 developed breathlessness and nocturnal cough. She was an ex-smoker. She had no history of eczema, asthma, or hay fever. Skin prick tests to common aeroallergens did not provoke immediate reactions, but these were elicited by the detergent enzymes with which she worked: cellulase, protease, and amylase. She had evidence of circulating specific IgE with increased RAST binding to the three enzymes (table 1). On provocation testing she had no change in $\mathrm{FEV}_{1}$ on exposure to lactose but a clear, repeatable dual response following exposure to cellulase. This reproduced her respiratory symptoms. Each test inhalation challenge was associated with a fall in histamine $\mathrm{PC}_{20}$.

\section{Case 2: Lipase}

A 52 year old man had worked as an engineer in a detergent manufacturing company since 1966. He was an ex-smoker with no history of asthma, hay fever, or eczema. He had intermittent sneezing, runny eyes and nose for several years, and in 2001 developed work related cough, wheeze, and breathlessness. Investigations by his occupational health service had identified raised levels of specific IgE to detergent lipase and protease; serial peak flow measurements had proved undiagnostic. At clinic he had immediate skin prick test reactions and increased RAST binding to lipase, protease, and amylase, but not to common aeroallergens. A bronchial challenge to lipase was undertaken in 2003. This reproduced his work related symptoms associated with a dual asthmatic response. This pattern recurred on a subsequent challenge and was associated with a fall in histamine $\mathrm{PC}_{20}$. There was no response to the inert challenge.

\section{Case 3: Lipase}

A 26 year old man had worked in the production of detergent tablets for seven years at the same site as Case 2. In early 2002 he had work related sneezing and a blocked nose and by the end of the same year had developed wheeze and chest tightness. He had never smoked and had no history of asthma, hay fever, or eczema. Investigations by his occupational health service identified raised levels of specific IgE to detergent lipase but no cross-shift changes in spirometry. At clinic he had immediate skin prick test reactions to grass pollen and cat dander, and in addition increased RAST binding to lipase, but not to the other enzymes with which he had worked (protease, amylase, and cellulase). Bronchial challenge provoked no response to an inert control, but did provoke a dose dependent dual asthmatic response to lipase with an associated fall in histamine $\mathrm{PC}_{20}$. The challenge test reproduced his work related symptoms.

\section{DISCUSSION}

These straightforward case reports show that cellulases and lipases can cause occupational asthma in the detergent industry. The diagnoses were confirmed by evidence of sensitisation and asthmatic reactions elicited by bronchial challenges with the relevant enzymes. Each challenge test provoked a dual asthmatic response with the reproduction of work related symptoms and an associated fall in histamine
$\mathrm{PC}_{20}$. Subsequent to the diagnoses of occupational asthma, Case 1 left her company, whereas Cases 2 and 3 continued to work for the same employer in non-enzyme areas.

A mixture of enzymes is now used in the manufacture of most biological detergents. Two cases were also sensitised to other enzymes and it is difficult to know whether these influenced the development of lipase and cellulase sensitisation. Animal studies have suggested that proteases potentiate the allergenicity of non-proteases, amylase and lipase. ${ }^{6}$

Cellulase has previously been shown by specific bronchial challenge tests to cause occupational asthma, in the pharmaceutical, ${ }^{7}$ baking, ${ }^{8}$ and enzyme production industries. ${ }^{9}$ We now describe for the first time occupational asthma to a cellulase derived from Humicola insolens. In baking and enzyme production the cellulase was derived from Aspergillus niger. "Cellulases" are a group of enzymes that hydrolyse cellulose to glucose. Because they may have different microbial origins, and different protein sequences, sensitisation to one cellulase cannot be assumed for another. To the best of our knowledge, occupational asthma has never previously been shown by specific bronchial challenge test with lipases. Interestingly Case 2 worked in a plant using only liquid enzyme preparations.

Despite encapsulation, sensitisation to detergent enzymes remains an important cause of occupational asthma. The use of these enzymes has been increasing over the past 15 years, and each of the four most commonly used detergent enzymes has now been described to cause occupational asthma. It would seem prudent to consider all enzymes to be potential sensitisers. Continued vigilance and appropriate preventative measures need to be taken by those working with enzymes.

\section{ACKNOWLEDGEMENTS}

We would like to acknowledge the contribution of Dr Peter Oliver.

\section{Authors' affiliations}

A Brant, A Hole, J Cannon, J Helm, C Swales, J Welch, A Newman

Taylor, P Cullinan, Department of Occupational and Environmental Medicine, Royal Brompton Hospital, Imperial College (NHLI), School of Medicine, London, UK

Correspondence to: Dr A Brant, Department of Occupational and Environmental Medicine, Royal Brompton Hospital, Imperial College (NHLI), 1b Manresa Rd, London SW36LR, UK; a.brant@ic.ac.uk

\section{Accepted 24 March 2004}

\section{REFERENCES}

1 Flindt ML. Pulmonary disease due to inhalation of derivatives of Bacillus subtilis containing proteolytic enzyme. Lancet 1969;1:1177-81.

2 Belin L, Hoborn J, Falsen E, et al. Enzyme sensitisation in consumers of enzyme-containing washing powder. Lancet 1970;2:1153-7.

3 Newhouse ML, Tagg B, Pocock SJ, et al. An epidemiological study of workers producing enzyme washing powders. Lancet 1970;1:689-93.

4 Juniper CP, How MJ, Goodwin BF, et al. Bacillus subtilis enzymes: a 7-year clinical, epidemiological and immunological study of an industrial allergen. J Soc Occup Med 1977;27:3-12.

5 Hole AM, Draper A, Jolliffe G, et al. Occupational asthma caused by bacillary amylase used in the detergent industry. Occup Environ Med 2000;57:840-2.

6 Sarlo K, Ritz HL, Fletcher ER, et al. Proteolytic detergent enzymes enhance the allergic antibody responses of guinea pigs to nonproteolytic detergent enzymes in a mixture: implications for occupational exposure. J Allergy Clin Immunol 1997; 100:480-7.

7 Losada E, Hinojosa M, Moneo I, et al. Occupational asthma caused by cellulase. J Allergy Clin Immunol 1986;77:635-9.

8 Quirce S, Cuevas M, Diez-Gomez M, et al. Respiratory allergy to aspergillusderived enzymes in bakers' asthma. J Allergy Clin Immunol 1992;9016 pt 1):970-8.

9 Merget R, Stollfuss J, Wiewrodt R, et al. Diagnostic tests in enzyme allergy. J Allergy Clin Immunol 1993;92:264-77. 